
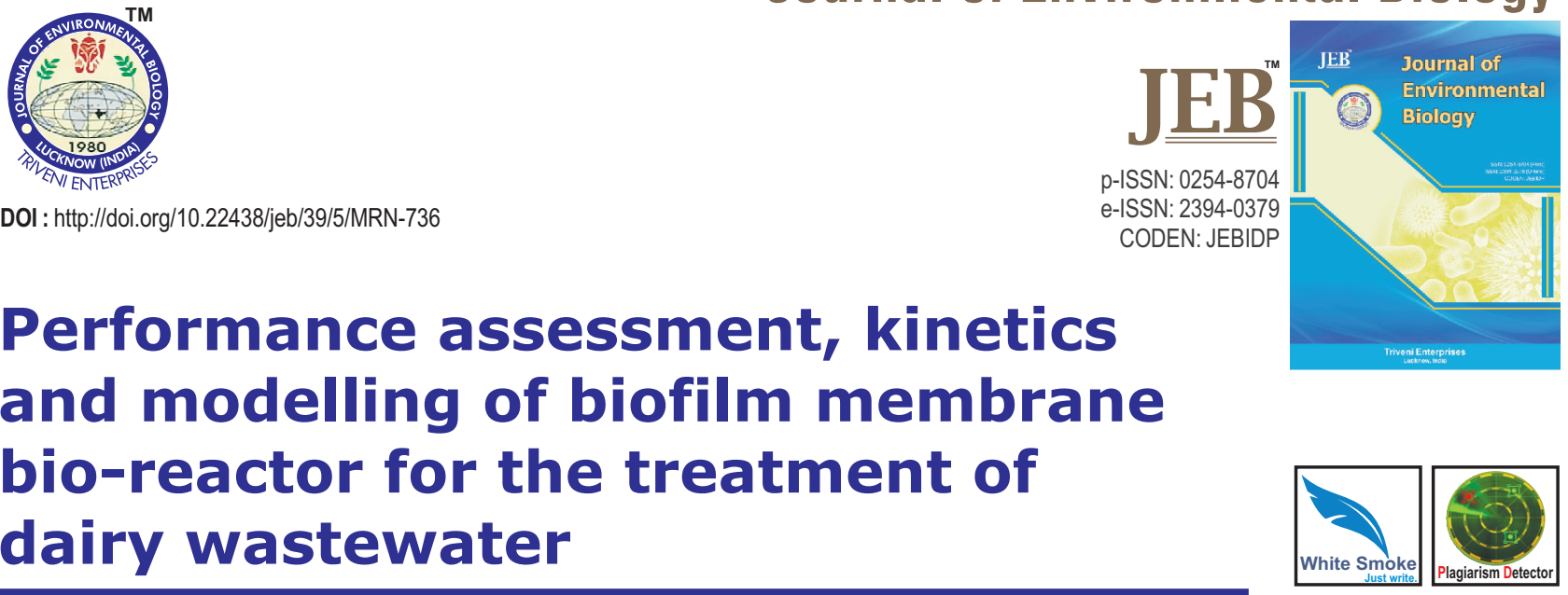

\title{
Performance assessment, kinetics and modelling of biofilm membrane bio-reactor for the treatment of dairy wastewater
}

Authors Info

\author{
V. Ravi Sankar ${ }^{1 *}$, S. Chandran ${ }^{1}$ \\ and D. Pradeep Pandiyan ${ }^{2}$ \\ 'Department of Civil \\ Engineering, Thiagarajar \\ College of Engineering, \\ Madurai-625 015, India \\ ${ }^{2}$ Water Supply and Wastewater \\ Department, Khatib and Alami \\ Engineering Consultants \\ Private Limited, \\ Bengaluru-560 025, India
}

*Corresponding Author Email : environmentengr@tce.edu

Key words

Biofilm MBR

BioWin Model

Biokinetic coefficient

Dairy wastewater

Publication Info

Paper received : 30.08 .2017

Revised received: 13.02.2018

Re-revised received : 22.03 .2018

Accepted: 04.04.2018

\section{Abstract}

Aim : The present study investigated the performance of a bench scale Biofilm Membrane Bioreactor (BF$M B R$ ) and determined relevant biokinetic coefficient for subsequent kinetic modelling and simulation studies for evaluating the feasibility of BF-MBR for treating dairy wastewater.

Methodology : The bench-scale BF-MBR was devised by combining conventional aerobic membrane bioreactor with a moving bed biofilm reactor. The bioreactor was operated at varying Hydraulic Retention Times (HRT) of four, six, and eight-hour to determine the optimum HRT and thereby, enhance reactor performance. Kinetic studies were also performed on the BF-MBR treated dairy effluent to determine the biokinetic coefficients like yield coefficient and other rate constants. Subsequently, kinetic modelling and simulation studies which incorporates the obtained biokinetic coefficients were performed using BioWin, a simulation software, used to optimize system design and performance.

Results : The results revealed that the Biofilm MBR that operated at an optimum HRT of six hours produced treated effluent with the following physico-chemical properties: Chemical Oxygen Demand $=60.90 \mathrm{mg} \mathrm{l}^{-1}$, Total Nitrogen $=9.61 \mathrm{mg} \mathrm{l}^{-1}$ and Total Phosphorus $=6.26 \mathrm{mg} \mathrm{l}^{-1}$ corresponding to removal efficiency of $97.25 \%, 91.8 \%$ and $64.8 \%$ respectively. The obtained average value of biokinetic coefficients were Yield Coefficient $=$ $0.617 \mathrm{mg} \mathrm{mg}^{-1}$, Decay rate $=0.1387$ per day, maximum specific growth rate $=2.5189$ per day and saturation constant $=888.917 \mathrm{mg} \mathrm{COD} \mathrm{l}^{-1}$. Also, the simulated effluent characteristics were
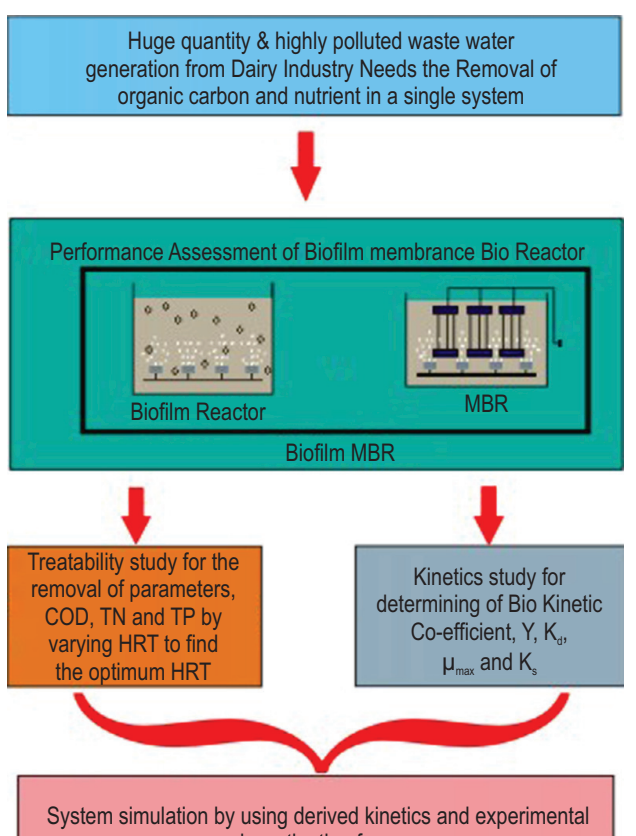
investigation from treatability study using BioWin Simulation software

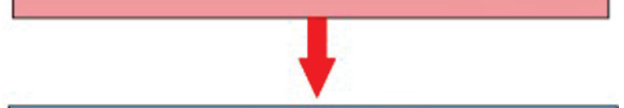

Analyse the suitability of Biofilm MBR for dairy Industry waste water

found to be closely related with those of an experimental investigation showing $R^{2}$ values of $0.9586,0.8394$ and 0.8362 for various concentrations of COD, TN and TP, respectively.

Interpretation : It was observed from the laboratory bench-scale performance and modelling studies that biofilm-membrane bio reactor is a suitable system for removal of organic and nutrient pollutant from dairy wastewater to meet the discharge standards. 


\section{Introduction}

Due to urbanization and increasing population, generation of domestic and industrial wastewater has been increasing (Vourch et al., 2008). Compared to other industrial sectors, the food industry consumes a greater amount of water for each unit of product. The dairy industry is one of the world's staple industries and is highly water intensive. India is the world's largest producer of milk and largest net exporter of dairy products in Asia (Ohlan, 2014); It is evidenced by the fact that Indian dairy market holds $17 \%$ of global market share in milk production (Verma et al., 2012). As per Annual Report (2013-14) of National Dairy Development Board, the Indian dairy industry is all set to experience a high growth rate in the next eight years with the demand likely to reach 200 million tons by 2022. With this growth rate, there will be a huge consumption of water for the processing, packaging, cooling, cleaning and sanitary processes (Tiwari et al., 2016) and it would subsequently result in large amount of wastewater generation (Chokshi et al., 2016). In well-managed facilities, generation of wastewater is between 2-10 litres of processed milk (Buntner et al., 2013).

Wastewater from dairy industries have high organic content, high level of nutrients, oil and fats as dairy industry is characterized by a variety of products like pasteurized milk, cheese, butter, curd, etc. (Cristian, 2010). These are the main source of pollution dishchared from of this type of industry (Shete et al., 2013). The typical range of Chemical Oxygen Demand, Total Nitrogen and Total Phosphorus of dairy wastewater is in the range of 2850-3550 mg l-1, 150-170 $\mathrm{mg} \mathrm{I}^{-1}$ and $30-34 \mathrm{mg} \mathrm{I}^{-1}$ respectively. Thus the treatment possibilities of dairy effluents have been attracting more and more attention (Slavov, 2017). Since dairy wastewaters is highly biodegradable, they can be biologically treated, by using aerobic and anaerobic process technologies. Generally, the wastewater from the dairy industries is treated either by natural treatment systems like constructed wetlands, lagoons, etc., or by conventional treatment systems such as Activated Sludge Process, Sequential Batch Reactors, aerobic filters, Up-flow Anaerobic Sludge Blanket reactors, etc.

However, conventional treatment technologies have not been effective for nutrient removal from dairy wastewater, hence researchers use advanced or modified treatment systems such as photo-catalytic methods (Rajesh Banu et al., 2008) Anaerobic biofilm reactors (Karadag et al., 2015), combined UASB and MBR (Buntner et al., 2013), and electrochemical treatment (Davarnejad et al., 2016). These systems suffer limitations such as intense energy requirements, inability to withstand shock loads, presence of some inhibitors, and so on.

Furthermore, to meet the stringent effluent discharge standards of Pollution Control Boards in India, advanced wastewater treatment processes and zero discharge treatment units are required (Tiwari et al., 2016). Interestingly, the MBR technology, an advanced biological treatment system, based on the integration of membrane filtration with biological reactors, is a suitable technology that has seen a significant growth in recent years (Judd, 2010). The MBR is efficient in achieving good effluent characteristics, because low molecular weight compounds are degraded by biomass of $M B R$, and non-degraded compounds along with soluble microbial products are primarily retained by the membranes (Andrade et al., 2013). In spite of its effectiveness, the MBR operation results in increased membrane fouling, efficiency reduction and frequent maintenance.

Consequently, several research groups have been experimenting to overcome the drawbacks of MBR and to improve operational efficiency through process modifications. One such modification is biofilm-assisted MBR. Biofilm MBR combines conventional membrane bioreactor with attached growth biofilm processes, in which biodegradation is carried out by suspended growth (i.e., activated sludge) and aided by the attached growth (i.e., biofilm). This occurs due to the addition of support media that provides a higher surface area for biofilm growth. As a result, the combined process has potentially a higher resistance of biomass to toxic substances/shock loads, improves filterability, lower fouling rate and higher fluxes (Ivanovic et al., 2012). In addition to this, the main advantage is higher nutrient removal due to the combination of nitrification and denitrification in the same reactor (Li et al., 2008). Also, the literature survey states that there is little information on kinetic coefficients of BFMBR which are essential to gain useful insight and understand the microbial activities like cell growth rate and consumption of substrate, and it can be used to simulate varied treatment system operating conditions, by using computer modelling software.

Computer modelling software has been applied in the field of wastewater engineering for the past two decades as they all have evolved principally as research tools (Langergraber et al., 2004). Mathematical modelling and simulation enable us to understand the rates at which the biochemical reactions of the system occur (Almquist et al., 2014), and they are necessary for a better understanding of the wastewater treatment plant to maximize the efficiency and the increased recovery from the treatment plants.

Activated sludge models (ASM1, ASM2, ASM2d, and ASM3) developed by the International Water Association (IWA) task group on mathematical modelling are most commonly used for simulating design and operation of biological wastewater treatment processes (Liwarska-Bizukojc et al., 2010). Most of the commonly used simulation software like ASIM, BioWin, GPS-X, WEST, and DESASS are incorporated with the activated sludge models (ASMs) or ASM-based models (Ferrer et al., 2008).

As biofilm MBR is still under experimental research (Zhang et al., 2017), a study was conducted primarily to assess the performance of Biofilm-MBR for the treatment of dairy wastewater, by varying the Hydraulic Retention Time (HRT). In this study an attempt was also made to find the optimum HRT to achieve the effluent quality, conforming to the discharge 
standards followed by the estimation of kinetic parameters of BF$M B R$, and subsequent modelling by using BioWin process simulation software.

\section{Materials and Methods}

Sample collection and characterization : The composite samples of dairy wastewater were collected during one shift in triplicate at the time intervals of two hours from the effluent treatment plant, located at the district Co-operative Milk Producers' Union Ltd., Madurai, and then analyzed for basic characteristics.

Experimental setup and procedure : For this study, a benchscale membrane bioreactor with 15 I working volume was fabricated and mounted with a flat sheet polyvinylidene fluoride membrane (SINAP-10). The membrane has a pore size of 0.1 microns and an effective membrane area of $0.1 \mathrm{~m}^{2}$. The system was aerated using three fine bubble diffusers, which were placed at the bottom of the reactor, right below the membrane to enhance membrane scouring by air bubbles and thereby to minimize fouling. Besides, two perforated acrylic plates were also placed one on each side of the membrane to ensure a uniform gas distribution and to prevent the dead zones in the reactor. A 15 I volume biofilm reactor was operated at $40 \%$ filling fraction, by filling $40 \%$ of the reactor volume with circular polypropylene carrier media. The diameter of the carrier media was $21 \mathrm{~mm}$. The reactor was aerated, using compressed air to keep the carrier media in suspension. Influent wastewater was introduced into the reactors, by means of flow controlled peristaltic pumps. The effluent was withdrawn with a suction pump, that operated on 12 min cycles: 10 min withdrawal followed by 2 min resting period. The suction pump flow was periodically reversed to backwash the membrane. The overall performance of the BF-MBR was evaluated by varying the Hydraulic Retention Time.

Initial process : The seed sludge was obtained from Avaniyapuram Sewage Treatment Plant, Madurai and stabilized for about 10 days in laboratory before feeding into the reactor. The seed sludge was then acclimatized to the dairy wastewater until the system reached a steady state. The steady state condition was achieved when the biomass concentration and effluent COD were nearly constant.

Performance study : The run cycle of the reactor was started after the system reached a stability which allows sufficient biofilm growth on the media. The process run was divided into four phases of different Hydraulic Retention Times (HRT) of two, four, six and eight hours. Each run-phase, starting with the two-hour HRT was run for a duration of ten days. The effluent parameters such as Chemical Oxygen Demand (COD), Total Nitrogen (TN) and Total Phosphorus (TP) values were analyzed daily as per the APHAstandard methods (2012).

Kinetic study : Following the performance study, the kinetic study was performed for the next thirty days. The data were collected in four phases, and the only parameters taken during steady state were considered. A steady-state condition is an unchanging condition in which both the biomass growth and effluent COD are nearly constant without much variation. The biokinetic coefficients were determined from lab-scale setup that operated at different HRTs by permitting the steady state condition to prevail for every adopted HRT (Al-Malack 2006., AlMalack et al., 2016). Similar studies were taken up for determining of bio-kinetic coefficients for dairy wastewater, using lab scale Aeration tank (Venkatesan et al., 2004). The following Monod equations were used to find the kinetic parameters such as Yield Coefficient ( $\mathrm{Y})$, Decay rate $(\mathrm{kd})$, Maximum specific growth rate $(\mu \mathrm{m})$ and saturation constant $\left(\mathrm{K}_{\mathrm{s}}\right)($ Metcalf etal., 2014).

$$
\begin{array}{ll}
\mathrm{Q}(\mathrm{So}-\mathrm{S}) / \mathrm{VX}=1 / \mathrm{Y}^{*} \mathrm{SRT}+\mathrm{kd} / \mathrm{Y} & - \text { Equation (1) } \\
\mathrm{SRT} /\left(1+\mathrm{SRT}{ }^{*} \mathrm{kd}\right)=\mathrm{Ks} / \mu \mathrm{m}^{*} \mathrm{~S}+1 / \mu \mathrm{m} & - \text { Equation (2) }
\end{array}
$$

Where,

Q-Flowrate; V-Volume; So - Initial substrate concentration; S - Effluent substrate concentration; SRT-Solid retention time; $\mathrm{X}$ - Biomass in bioreactor ( $\mathrm{mg} \mathrm{l}^{-1}$ ) as MLVSS; $\mathrm{Y}$-Yield; $\mathrm{kd}$-Decay rate; $\mathrm{K}_{\mathrm{s}}$ - Saturation constant; $\mu \mathrm{m}$ - Maximum specific growth rate.

Modelling: The performance and kinetic study data were used to model the biofilm reactor for the process optimization. The

Table 1: Concentration values of Chemical Oxygen Demand, Total Nitrogen and Total Phosphorus in Biofilm Membrane Bio Reactor

\begin{tabular}{llllll}
\hline $\begin{array}{l}\text { Phase } \\
\text { Operational days (day) }\end{array}$ & & I & II & III & IV \\
Hydraulic retention time (hours) & $\mathbf{2 6 - 3 5}$ & $\mathbf{3 6 - 4 5}$ & $\mathbf{4 6 - 5 5}$ & $\mathbf{5 6 - 6 5}$ \\
\hline Effluent COD $\left(\mathrm{mg} \mathrm{l}^{-1}\right)$ & Mean & $\mathbf{2}$ & $\mathbf{4}$ & $\mathbf{6}$ & $\mathbf{8}$ \\
& Maximum & 177.8 & 113.6 & 60.9 & 55.3 \\
& Minimum & 214.85 & 139.54 & 77.5 & 70.8 \\
Effluent TN $\left(\mathrm{mg} \mathrm{I}^{-1}\right)$ & 155.05 & 95.24 & 48.73 & 42.1 \\
& Mean & 33.75 & 18.9 & 9.6 & 6.61 \\
& Maximum & 37.7 & 29.5 & 17.8 & 7.4 \\
Effluent TP $\left(\mathrm{mg} \mathrm{l}^{-1}\right)$ & Minimum & 32.1 & 15.34 & 7.552 & 5.66 \\
& Mean & 9.26 & 8.02 & 6.26 & 4.72 \\
& Maximum & 9.434 & 8.348 & 7.12 & 5.07 \\
& Minimum & 9.04 & 7.654 & 5.70 & 4.72 \\
\hline
\end{tabular}


simulations of Biofilm-Membrane Bio-Reactor (BF-MBR) were carried out using BioWin simulation software (Version 5.2, EnviroSim Associates Ltd., Canada). BioWin simulator can be used for biological wastewater treatment plant design, analysis and training. It is widely used by consulting engineers, treatment plant operators and academic institutions as it involves faster and steady-state solver, integrated models, etc. It employs different established models such as Activated Sludge Models (ASM1, ASM2, ASM2d and ASM3), Anaerobic Digestion Model and various Bio-film models. In this study, activated sludge digestion (ASDM) model integrated with BioWin was used to assess the performance of BF-MBR under different operating conditions. The model was created in BioWin simulation Software (Fig. 1).

Some of the modeling input parameters were experimentally determined through kinetic study and experimental analysis (as indicated in Table 5) and default values were used for other parameters. Once the model of lab scale plant was set up, simulations were carried out for steady state conditions. Some of the influent and effluent characteristics such as TP, TN, COD were recorded for each trial run and they were used for calibration and the rest for the validation process.

Initially, the simulations were made with the default values of kinetic and stoichiometric parameters of BioWin ASDM model to ascertain the predictability of model in-terms of effluent characteristics (COD, TN, and TP), and the model was simulated by using a set of experimental data (Phase III - six-hour HRT). In this scenario, a sensitivity analysis was made to obtain a better sense of the impact of various parameters of the model. It was performed by varying the default values of kinetic and stoichiometric parameters by $\pm 50 \%$ (Eldyasti et al., 2012, Ersu et al., 2008). Thus, fifteen parameters i.e., wastewater fractions Fbs, Fus, Fna and Fpo4, maximum growth rate of heterotrophs, yield and aerobic decay rate of heterotrophs, hydrolysis rate of heterotrophs, maximum specific growth rate of autotrophs, decay rate of autotrophs ( $\mathrm{kd}$ ), yield of autotrophs, substrate half saturation for autotrophs, maximum specific growth rate, decay rate of phosphorus accumulating organisms and nitrogen in the endogeneous residue were selected for sensitivity analysis with the order of calibration adopted from Cosenza et al. (2013). Among the selected parameters, four wastewater fractions i.e., Fbs, Fus, Fna and $\mathrm{FPO}_{4}$ were determined experimentally and the three more parameters i.e., maximum growth rate of heterotrophs, yield and aerobic decay rate of heterotrophs were obtained through kinetic study.

\section{Results and Discussion}

The influent water characterization of wastewater was performed and the result revealed COD $2215 \pm \mathrm{mg} \mathrm{l}^{-1}$, Total Nitrogen $118 \pm 54 \mathrm{mg} \mathrm{l}^{-1}$, and Total Phosphorus $17.8 \pm 6.4 \mathrm{mg} \mathrm{l}^{-1}$. The average COD values of the reactor effluent for different HRTs were analyzed and found to be $177.8 \mathrm{mg} \mathrm{l}^{-1}, 113.6 \mathrm{mg} \mathrm{l}^{-1}, 60.9 \mathrm{mg} \mathrm{l}^{-}$ ${ }^{1}$ and $55.3 \mathrm{mg} \mathrm{I}^{-1}$ for two, four, six and eight-hour HRT respectively. The effluent total nitrogen concentration values were $33.75 \mathrm{mg} \mathrm{l}^{-1}$, $18.90 \mathrm{mg} \mathrm{l}^{-1}, 9.6 \mathrm{mg} \mathrm{l}^{-1}$ and $6.61 \mathrm{mg} \mathrm{l}^{-1}$ for two, four, six and eighthour HRT. Similarly, the effluent Total Phosphorus concentrations obtained were $9.26 \mathrm{mgl}^{-1}, 8.02 \mathrm{mgl}^{-1}, 6.26 \mathrm{mgl}^{-1}$ and $4.72 \mathrm{mgl}^{-1}$ for the two, four, six and eight-hour HRT (Table1). The system showed average COD removal efficiencies of $91.97 \%, 94.87 \%$, $97.25 \%$ and $97.5 \%$ (Fig. 2A) for two, four, six and eight hour HRT, respectively which was found similar to all other relevant studies (Table 2). The higher COD removal capacity was due to greater

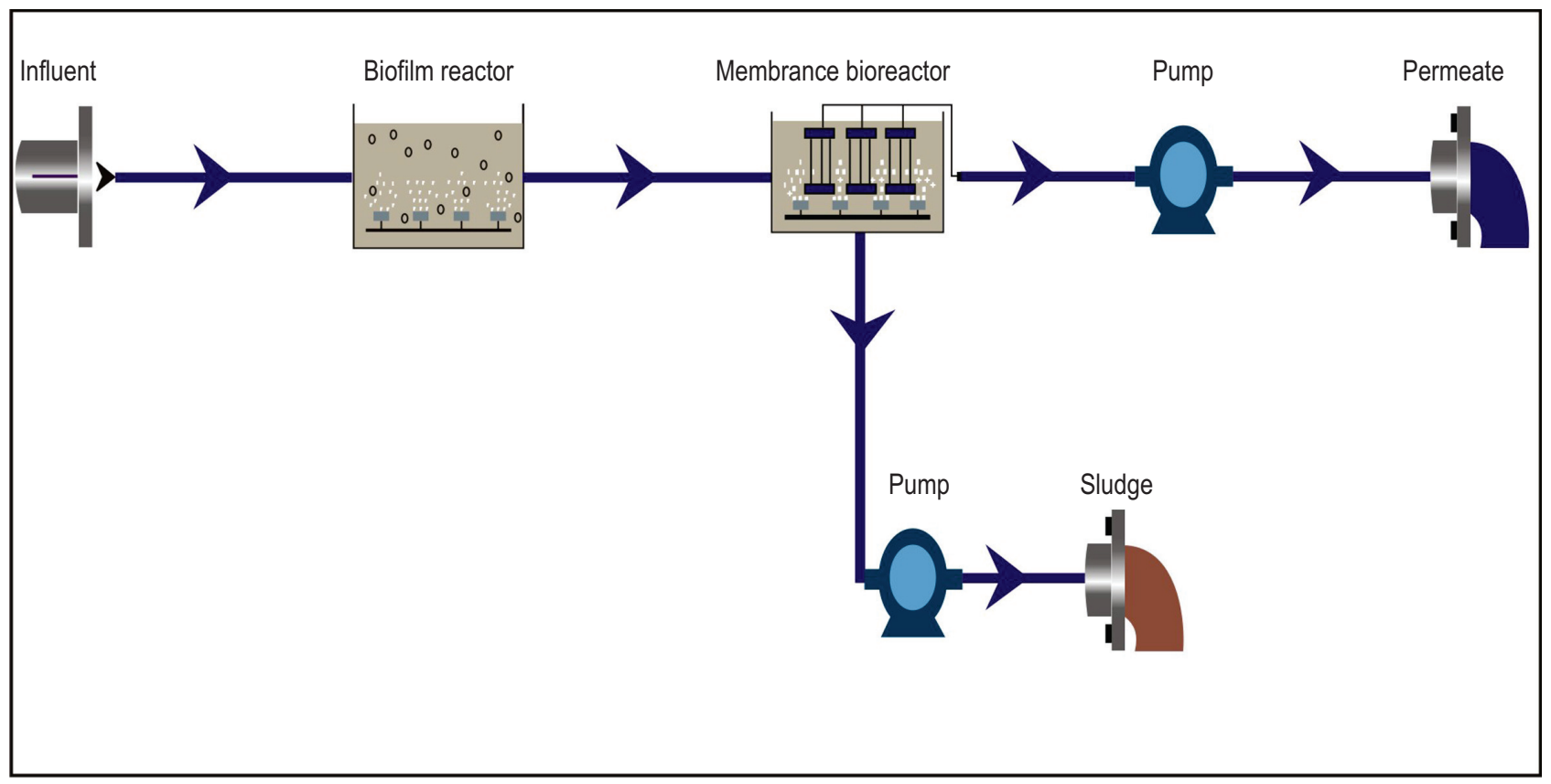

Fig.1: Schematic modelling of BF-MBR treatment scheme using BioWin simulation Software 

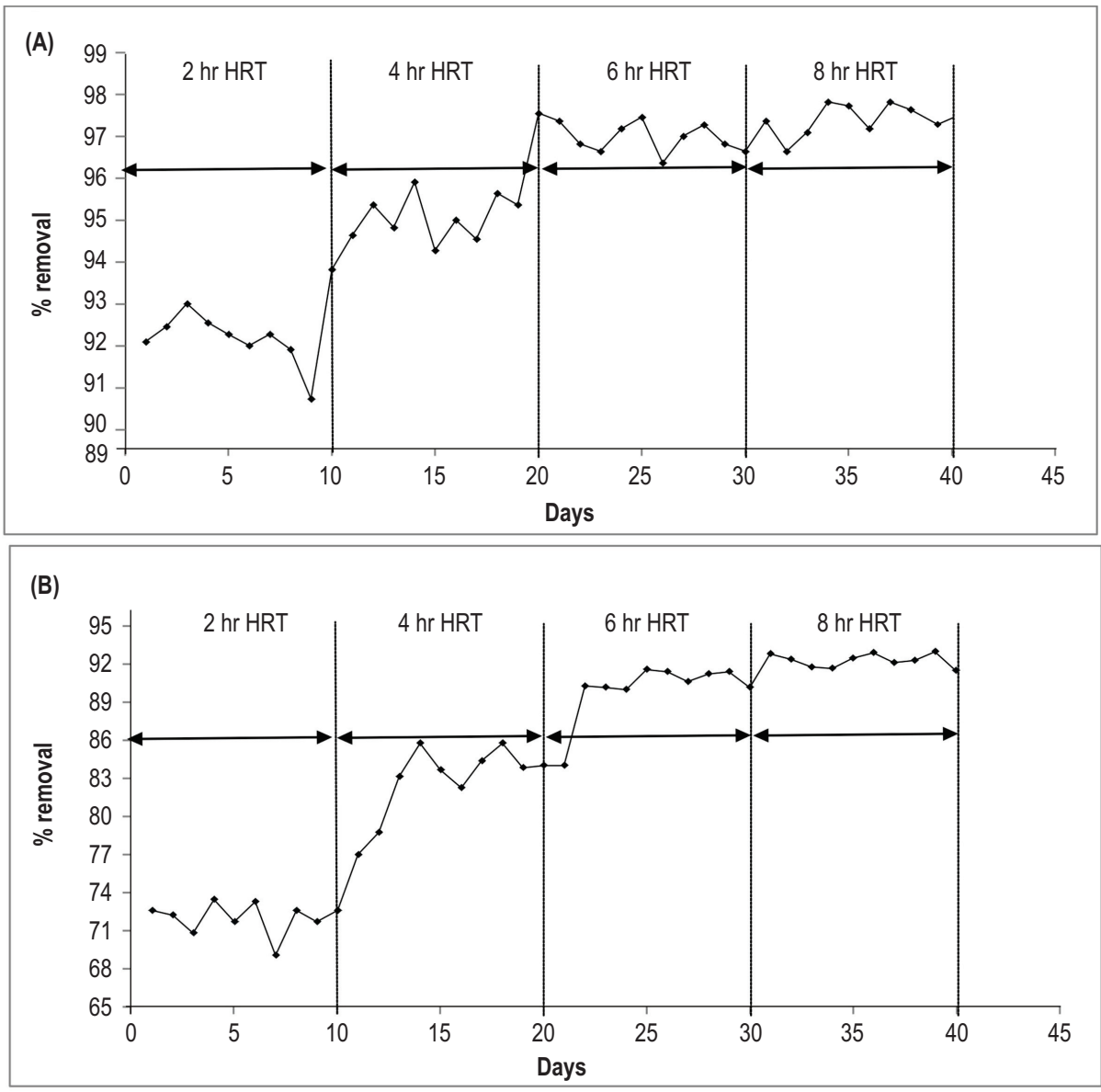

(C)

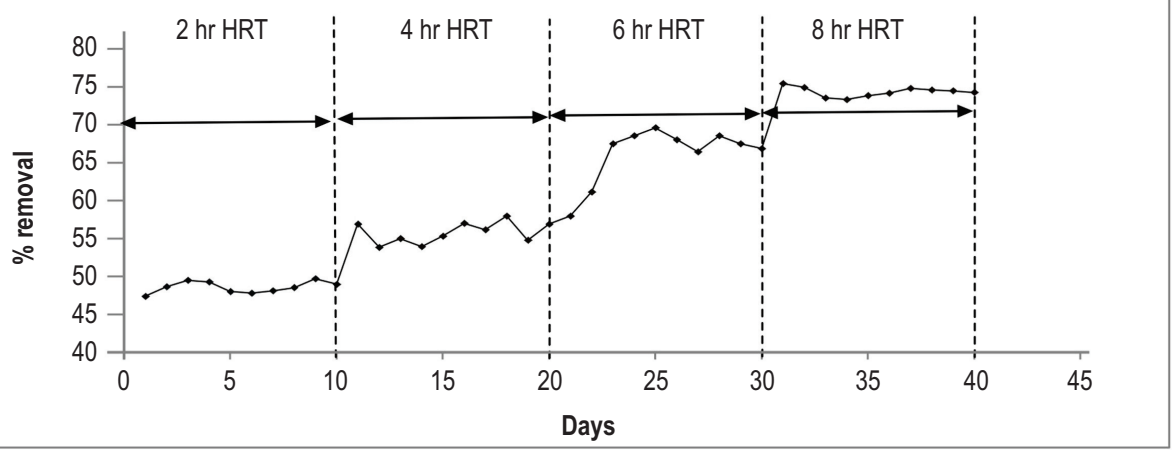

Fig. 2 : Removal performance of BF-MBR against various HRT for (A) Chemical Oxygen Demand, (B) Total Nitrogen and (C) Total Phosphorus

biomass activity of the biofilm that is aided with the higher surface area of carriers for biofilm growth (Zhang et al., 2017). However, the maximum COD removal efficiency of $97.25 \%$ was observed at six-hour HRT. Afterwards no significant changes were noted in the removal efficiency at higher HRT. Apparently, the lower removal efficiency at two-hour HRT could be attributed to incomplete oxidation of organic matters by bacteria which requires sufficient time to effectively oxidize the organic matter into a new cellular material, carbon dioxide and water (Sun etal., 2010).

The nitrate removal efficiencies were $71.4 \%, 84 \%, 91.8 \%$ and $94.4 \%$ (Fig. 2B) for two, four, six and eight-hour HRT, respectively. Nitrogen removal process was enhanced by variation in dissolved oxygen concentration which was observed 

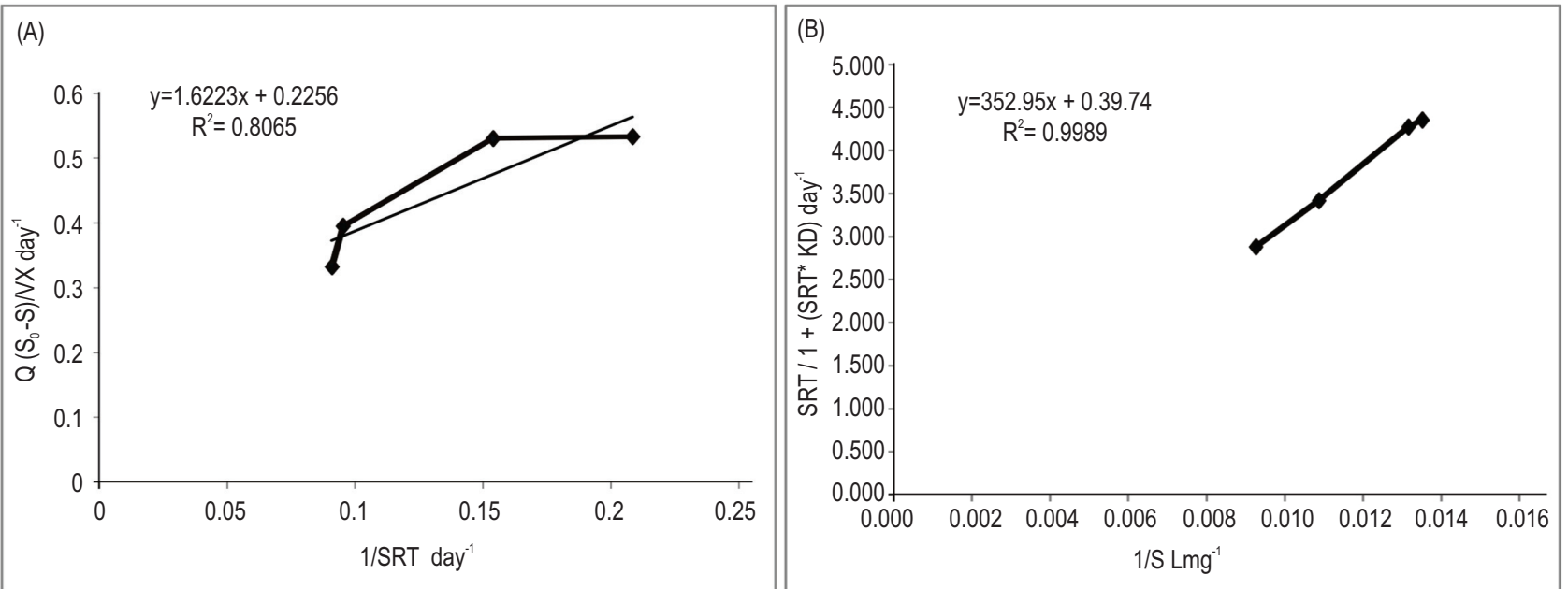

Fig. 3 : Determination of Coefficients for $(A) Y$ and $K_{d}$ and $(B) K s$ and $\mu_{\max }$

along the cross-section of carriers. DO decreased from periphery to the inner side of the carriers, providing oxic/aerobic zone at the periphery of heterotrophs, nitrifiers and inner anoxic/anaerobic zone for denitrifiers. Nitrification takes place at the periphery and denitrification in the deeper zone of the carriers (Yang et al., 2009). The function of the biofilm attached to the suspended carriers was similar to that of larger biological flocs, and their increased size and inner space provided a better condition for forming local anoxic zones for denitrification within the attached biomass (Ivanovic et al., 2012). Supporting this, Khan et al. (2011) state that the higher nitrogen removal efficiency observed in Attached Growth MBR (AG-MBR) compared to the Suspended Growth MBR (SG-MBR) was due to the simultaneous nitrification denitrification process occurring in the bio-carriers. Moreover, the carriers enhance this process by preventing the wash-out of biofilm that contains variety of bacterial communities that enhance the simultaneous nutrient removal. Further, the removal efficiency of nitrates showed a decreasing trend with shorter HRT. The effect of operating conditions, predominantly HRT, influences the competition between the nitrifying and heterotrophic bacteria, and the contact time for biological uptake. Both the bacterial competition and insufficient contact time played a key role in the removal process (Nguyen et al., 2014).

Similarly, phosphorus removal efficiencies were observed to be $48 \%, 55 \%, 64.8 \%$ and $73 \%$ (Fig. 2C) for two, four,

Table 2 : Comparative performance of Biofilm MBR for different types of wastewater

\begin{tabular}{|c|c|c|c|c|c|}
\hline \multirow[b]{2}{*}{ Type of wastewater } & \multicolumn{4}{|c|}{ Removal efficiencies (\%) } & \multirow[b]{2}{*}{ Reference } \\
\hline & $\begin{array}{l}\text { Chemical Oxygen } \\
\text { Demand (COD) }\end{array}$ & $\begin{array}{l}\text { Ammonical } \\
\text { Nitrogen }\left(\mathrm{NH}_{4}-\mathrm{N}\right)\end{array}$ & $\begin{array}{l}\text { Total Nitrogen } \\
\text { (TN) }\end{array}$ & $\begin{array}{l}\text { Total Phosphorus } \\
\text { (TP) }\end{array}$ & \\
\hline Municipal wastewater & 95 to 98.1 & 83.1 to 92.1 & 46.8 to 68.7 & 32.5 to 51.7 & (Jiang et al., 2017) \\
\hline Synthetic wastewater & 95 & 99.65 & - & - & (Di Trapani et al., 2014) \\
\hline Domestic wastewater & 95 to 99 & 98 & 73 & - & (Subtil et al., 2014) \\
\hline Municipal wastewater & 94.2 & 97.4 & 51 & 80.5 & (Liu et al., 2010) \\
\hline Synthetic wastewater & 97.7 & 96 & 41 & - & (Liang et al., 2010) \\
\hline Synthetic wastewater & 95.6 & 91.8 & 65.3 & - & (Yang et al., 2009) \\
\hline Dairy wastewater & 92 to 98 & - & 71 to 94 & 48 to 73 & This Study \\
\hline
\end{tabular}

Table 3 : Observed and calculated values for the determination of bio-kinetic coefficients using Monod equations

\begin{tabular}{|c|c|c|c|c|c|c|c|c|c|}
\hline $\begin{array}{l}\text { Steady } \\
\text { state, } \\
\text { (Days) }\end{array}$ & $\begin{array}{l}\text { Flow rate, } \\
Q(L / d)\end{array}$ & $\begin{array}{l}\text { Biomass } \\
\text { in bioreactor, } \\
X\left(\mathrm{mg} \mathrm{l}^{-1}\right)\end{array}$ & $\begin{array}{l}\text { Initial substrate } \\
\text { concentration, } \\
\text { So }\left(\mathrm{mg} \mathrm{l}^{-1}\right)\end{array}$ & $\begin{array}{l}\text { Effluent substrate } \\
\text { concentration, } \\
\mathrm{S}\left(\mathrm{mg} \mathrm{l}^{-1}\right)\end{array}$ & $\begin{array}{l}\text { Solid retention } \\
\text { time, SRT, } \\
\text { (days) }\end{array}$ & $\begin{array}{l}Q\left(S_{-} S_{0}\right) / \\
\operatorname{VX}(1 / \text { day })\end{array}$ & $\begin{array}{l}\text { 1/SRT } \\
\text { (1/day) }\end{array}$ & $\begin{array}{l}\text { SRT/1+ } \\
\left(\text { SRT*K }_{d}\right) \\
\text { (Day) }\end{array}$ & $\begin{array}{l}1 / \mathrm{S} \\
\left(\mathrm{Lm} \mathrm{g}^{-1}\right)\end{array}$ \\
\hline $68-72$ & 36 & 10300 & 1978 & 74 & 11 & 0.3327 & 0.0910 & 4.355 & 0.014 \\
\hline $74-78$ & 42 & 10750 & 2100 & 76 & 10.5 & 0.3953 & 0.0952 & 4.274 & 0.013 \\
\hline 83-87 & 42 & 11115 & 2900 & 92 & 6.5 & 0.5305 & 0.1538 & 3.418 & 0.011 \\
\hline $92-96$ & 42 & 11268 & 2970 & 108 & 4.8 & 0.5333 & 0.2083 & 2.881 & 0.009 \\
\hline
\end{tabular}



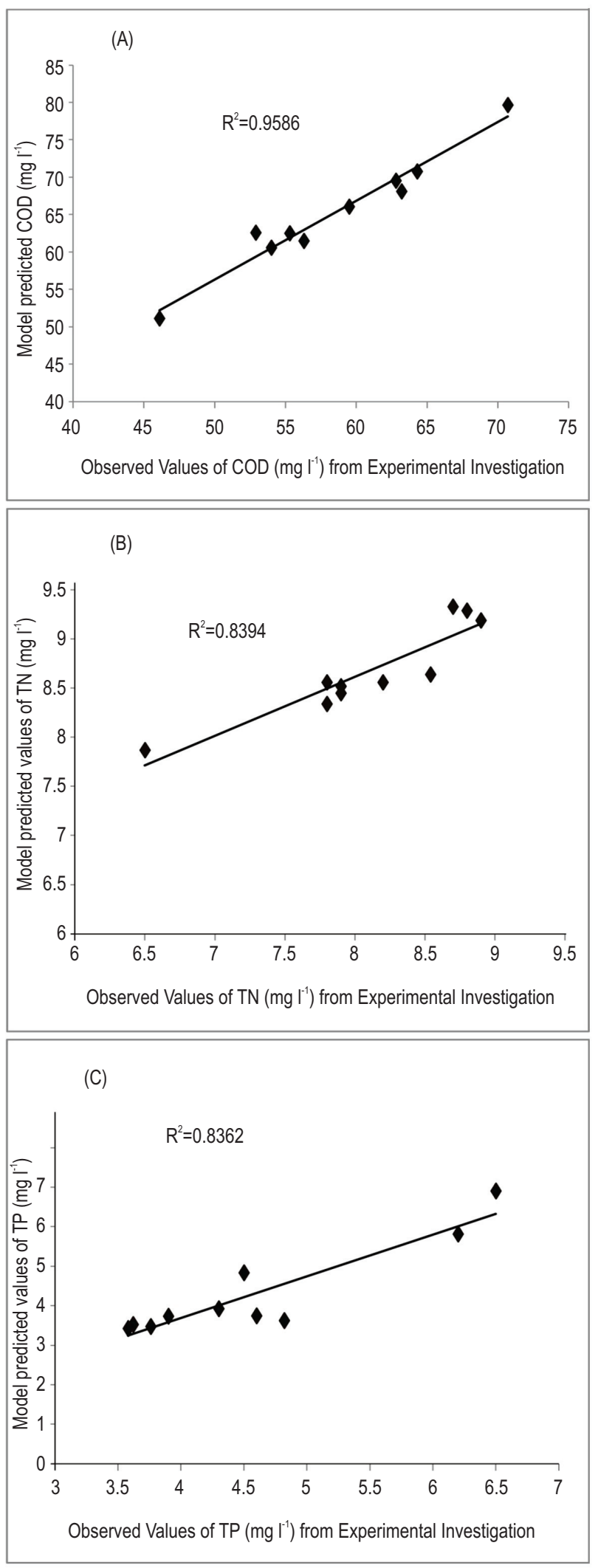

Fig. 4 : Model Predicted values Vs. Observed values for (A) Chemical Oxygen Demand (B) Total Nitrogen and (C) Total Phosphorus six and eight-hour, HRT respectively. In the present study, phosphate removal results were found to be comparatively closer with that the result of Liu et al. (2010), who observed $80.5 \%$ removal from domestic wastewater. Fascinatingly, many studies have not investigated phosphate removal, but the research related to BF-MBR on simultaneous removal is remarkably significant. Therefore, this study attempts to throw light on the phosphate removal to gain a better understanding of the competition among the ordinary heterotrophic bacteria, nitrifying bacteria and phosphate accumulating organisms in wastewater. In addition to this, the higher removal efficiency of nitrogen and phosphate in BF-MBR system was high due to longer growth cycle offered to nitrifiers and phosphate accumulating organisms in the high surface area carriers in the biofilm reactor. In contrast, common treatment technology like activate sludge process is ineffective in removing nutrients because of non-conducive conditions for nitrifiers and phosphate accumulating organisms which have a lower growth rate than heterotrophs (Ekama, 2015).

Fig. 3 (A \& B) shows determination of bio-kinetic coefficients using the equations (1) and (2). The value of various kinetic parameters are as follows : $Y=0.617 \mathrm{mg} / \mathrm{mg}, K_{d}$ $=0.1387$ per day, $\mu \mathrm{m}=2.5189$ per day and $\mathrm{K}_{\mathrm{s}}=888.92 \mathrm{mg} \mathrm{COD}$ $1^{-1}$. (Table 3) Except for the value of $K_{s}$, the value of other coefficients were found to be similar to the values reported by Kaewsuk et al. (2010); Mardani et al. (2011) and Al-Malack (2006). Table 4 presents a comparison among the results of the current study and those reported in the published literature for various types of wastewater. High $\mathrm{K}_{\mathrm{s}}$ value could be possibly due to high soluble substrate concentration. Additionally, microorganism having high $\mathrm{K}_{\mathrm{s}}$ value would exhibit maximum specific growth rate, and would take up the substrate quickly and grow rapidly (Al-Malack et al., 2016). Furthermore, the obtained $\mathrm{K}_{\mathrm{s}}$ value was found to be approximately closer to that reported in a study by Venkatesan et al. (2004) who reported a $\mathrm{K}_{\mathrm{s}}$ value of $867.76 \mathrm{mg} \mathrm{l}^{-1}$ in a lab scale activated sludge process plant treating dairy wastewater. Thus, the obtained biokinetic parameters were used as input for the model.

The simulations carried out by using the default values of parameters revealed that there was discrepancy between the measured and simulated values of effluent characteristics (COD, TN and TP) Also, the results of sensitivity analysis established four parameters such as maximum specific growth rate of autotrophs, decay rate of autotrophs $K_{d}$, hydrolysis rate of heterotrophs and nitrogen in the endogeneous residue as sensitive parameters. On the other hand, the parameters obtained through kinetic studies like yield of heterotrophs and decay rate of heterotrophs had more impact on effluent total nitrogen and total phosphorus concentration. Similar observation was also reported by Ersu et al. (2008). In-addition to this, Eldyasti et al. (2012) observed that the yield coefficient of heterotrophs was a very influential parameter for effluent characteristics.

This was due to the fact that both heterotrophs and phosphorus accumulating organisms depend on organic matter 
Table 4 : Bio kinetic coefficients of other studies at Chemical Oxygen Demand -A comparison

\begin{tabular}{llllll}
\hline Substrate & $\mathbf{Y}\left(\mathrm{mg} \mathrm{mg}^{-1}\right)$ & $\mathbf{K}_{\mathrm{d}}\left(\mathbf{d}^{-1}\right)$ & $\boldsymbol{\mu}_{\mathrm{m}}\left(\mathbf{d}^{-1}\right)$ & $\mathbf{K}_{\mathrm{s}}\left(\mathrm{mg} \mathrm{COD} \mathrm{l}^{-1}\right)$ & Source \\
\hline Dairy wastewater & 0.617 & 0.1387 & 2.5189 & 888.917 & This Study \\
Dairy wastewater & 0.2281 & 0.1383 & 1.69 & 174 & Kaewsuk et al., 2010 \\
Municipal wastewater & $0.62-1.25$ & $0.02-0.031$ & $1.96-3.17$ & $311.7-508$ & Sh. Mardani et al., 2011 \\
Synthetic wastewater & $0.487-0.583$ & $0.151-0.0261$ & $1.28-6.46$ & $289-2933$ & Al-Malack, 2006 \\
\hline
\end{tabular}

Table 5 : Summary of Calibrated Biowin Model Parameters for MBR

\begin{tabular}{|c|c|c|}
\hline Parameters & Default & Value adopted \\
\hline \multicolumn{3}{|l|}{ Autotrophs } \\
\hline Maximum specific growth rate & 0.9 & $0.21 \#$ \\
\hline Substrate $\left(\mathrm{NH}_{3}\right)$ half saturation & 0.7 & 0.7 \\
\hline Oxic decay rate & 0.17 & $0.2 \#$ \\
\hline Anoxic/Anaerobic decay rate & 0.08 & 0.08 \\
\hline $\mathrm{CO}_{2}$ half saturation for autotrophs & 0.01 & 0.01 \\
\hline Yield (Aerobic) & 0.07 & 0.07 \\
\hline \multicolumn{3}{|c|}{ Heterotrophs } \\
\hline Maximum specific growth rate & 3.2 & 2.5189 * \\
\hline Substrate half saturation & 5.0 & 5.0 \\
\hline Anoxic growth factor & 0.5 & 0.5 \\
\hline Oxic decay & 0.62 & $0.1387^{*}$ \\
\hline Anoxic/Anaerobic decay rate & 0.3 & 0.3 \\
\hline Hydrolysis rate (AS) & 2.10 & $3.15 \#$ \\
\hline Yield & 0.666 & $0.6170 *$ \\
\hline \multicolumn{3}{|c|}{ Phosphate Accumulating Organisms (PAO) } \\
\hline Maximum specific growth rate & 0.95 & 0.95 \\
\hline Substrate half saturation & 0.1 & 0.1 \\
\hline Anoxic/Anaerobic decay rate & 0.04 & 0.04 \\
\hline $\mathrm{N}$ in the endogenous residue & 0.070 & $0.010 \#$ \\
\hline \multicolumn{3}{|c|}{ Wastewater fractions } \\
\hline Fbs - Readily biodegradable (including acetate) [gCOD/g of total COD] & 0.16 & $0.29^{*}$ \\
\hline Fus - Unbiodegradable soluble [gCOD/g of total COD] & 0.05 & $0.02^{*}$ \\
\hline Fna - Ammonia $\left[\mathrm{gNH}_{3}-\mathrm{N} / \mathrm{gTKN}\right]$ & 0.66 & $0.7^{*}$ \\
\hline Fpo4 - Phosphate $\left[\mathrm{gPO}_{4}-\mathrm{P} / \mathrm{gTP}\right]$ & 0.5 & $0.8^{*}$ \\
\hline
\end{tabular}

*denotes experimentally determined values and ${ }^{*}$ denotes calibrated values

as their substrate. If the yield of heterotrophs, which consumes most of the organic substrate reduces, the substrate available for conversion into polyhydroxybutyrate by PAO will increase. The adopted value of yield of heterotrophs was slightly less than the value reported by Liwarska-Bizukojc et al. (2010). Also, aerobic hydrolysis rate has a larger impact on COD and TP than TN (Ersu et al., 2008). This can be connected with the fact that hydrolysis process does not consume any nitrogen directly ( $\mathrm{Ni}$ and $\mathrm{Yu}$, 2008). All these parameters were found to be within the range as suggested by Henze et al. (1987) such as $\mu \mathrm{m}$ of heterotrophs (0.6/day-0.8/day), $\mu \mathrm{m}$ of autotrophs (0.2/day-1/day), hydrolysis rate $(1.5 /$ day-4.5/day), yield of heterotrophs $(0.38-0.75)$ and yield of autotrophs $(0.07-0.28)$. Thus, the obtained bio-kinetic parameters from kinetic study were fitted well into the model which in turn ascertained the accuracy of the model.

Once the calibration of model was done, the model was validated by second set of data (i.e., Phase IV - eight-hour HRT data). The strength of association between the model predicted values and the observed values from experimental investigation for the effluent COD, Total Nitrogen and Total Phosphorus under different HRT values was calculated by using linear regression. Fig. 4 ( $A, B$ \& $C$ ) shows that there is a good agreement between the predicted and the measured values with $R^{2}$ value as 0.9586 , 
0.8394 and 0.8362 for COD, Total Nitrogen and Total Phosphorus, respectively. Thus, the calibrated model prediction value matches closely with the experimental effluent quality. The study proves that biofilm MBR obtained by integrating biofilm process and membrane filtration would exhibit higher treatment performance for removing organic matter, as well as nutrients. Hence, as inferred from the performance, kinetic and modelling studies, it was learnt that the Biofilm MBR is highly feasible for the treatment of dairy wastewater, since it exhibits higher removal efficiency at reduced HRT which would favor smaller reactor volume, resulting in reduced footprint, compared to other advanced treatment processes. This study also provides a base for studying the suitability of BF-MBR for other types of wastewater and operating conditions.

\section{Acknowledgments}

The authors acknowledge Technical Education Quality Improvement Programme (TEQIP) of Government of India for funding the reactor setup. They are also thankful to R. Manthiram Karthik, Research Scholar, Environmental and Water Resources Engineering, Indian Institute of Technology, Madras for his support in modeling, using BioWin software for this research study.

\section{References}

Al-Malack, M. H.: Determination of biokinetic coefficients of an immersed mermbrane bioreactor. J. Membr. Sci., 271, 47-58 (2006).

Al-Malack, M. H. and G. R. Aldana: Biokinetic coefficients of anaerobic immersed membrane bioreactor (AnlMBR) treating dairy wastewater. Desalin. Water Treatm., 57, 28600-28609 (2016).

Almquist, J., M.Cvijovic, V. Hatzimanikatis, J. Nielsen and M. Jirstrand: Kinetic models in industrial biotechnology-Improving cell factory performance. Metabolic Eng., 24, 38-60 (2014).

Andrade, L. H., G. E. Motta and M. C. S. Amaral: Treatment of dairy wastewater with a mermbrane bioreactor. Brazilian. J. Chem. Eng., 30, 759-770 (2013).

APHA: Standard Methods for the Examination of Water and Wastewater. $22^{\text {id }}$ Edn., APHA, AWWA, WPCF, Washington DC, USA(2012).

Buntner, D., A. Sánchez and J. M. Garrido: Feasibility of combined UASB and MBR system in dairy wastewater treatment at ambient temperatures. Chem. Eng. J., 230, 475-481 (2013).

Chokshi, K., I. Pancha, A. Ghosh and S. Mishra: Microalgal biomass generation by phycoremediation of dairy industry wastewater: An integrated approach towards sustainable biofuel production. Bioresour. Technol., 221, 455-460 (2016).

Cosenza, A., G. Mannina, M. B. Neumann, G. Viviani and P. A. Vanrolleghem: Biological nitrogen and phosphorus removal in membrane bioreactors: Model development and parameter estimation. Bioprocess Biosyst. Eng., 36, 499-514 (2013).

Cristian, 0. : Characteristics of the urtreated wastewater produced by food industry. Analele Universitătii din Oradea, Fascicula: Protectia Mediului, 15, 709-714 (2010).

Davarnejad, R. and M. Nikseresht: Dairy wastewater treatment using an electrochemical method: Experimental and Statistical study. J. Elec. Chem., 775, 364-373(2016).

Di Trapani, D., G. Di Bella, G. Mannina, M. Torregrossa and G. Viviani: Comparison between moving bed-membrane bioreactor (MB-MBR) and membrane bioreactor (MBR) systems: Influence of wastewater salinity variation. Bioresour. Technol., 162, 60-69(2014).
Ekama, G. A.: Review-Recent developments in biological nutrient removal. Water $S A, 41,515-524$ (2015).

Elangovan, C. and A. S. S. Sekar: Performance evaluation of up-fiow anaerobic sludge blanket reactor process for dairy wastewater treatment. J. Environ. Biol., 36, 1305-1310 (2015).

Eldyasti, A., G. Nakhla and J. Zhu: Development of a calibration protocol and identification of the most sensitive parameters for the particulate biofilm models used in biological wastewater treatment. Bioresour. Technol., 111, 111-121 (2012).

EnviroSim, BioWin Marual, version 5.2, https://envirosim. com/ products/ biowin (Accessed on 14.08.2017).

Ersu, C. B., S.K. Ong, E. Arslankaya and P. Brown: Comparison of recirculation configurations for biological nutrient removal in a membrane bioreactor. Water Res., 42, 1651-1663 (2008).

Ferrer, J., A. Seco, J. Serralta, J. Ribes, J. Manga, E. Asensi, J. J. Morenilla and F. Llavador: DESSAS: A software tool for designing, simulating and optimising WWTPs. Environ. Modell. Softw., 23, 19-26 (2008).

Henze, M., C. P. L. Grady, W. Gujer, G. V. R. Marais and T. Matsuo: Activated sludge model No.1. IAWPRC, London, (1987).

Ivanovic, I. and T. O. Leiknes: The biofilm membrane bioreactor (BFMBR)-a review. J. Desali. Wat. Treat., 37, 288-295(2012).

Jiang, Q., H. H. Ngo, L. D. Nghiem, F. I. Hai, W. E. Price, J. Zhang, S. Liang, L. Deng and W. Guo: Effect of hydraulic retention time on the performance of a hybrid moving bed biofilm reactor-membrane bioreactor system for micropollutants removal from municipal wastewater. Bioresour. Technol., 247, 1228-1232 (2017).

Judd, S.: The MBR book Principles and Applications of Membrane Bioreactors for Water and Wastewater Treatment. $2^{\text {nt }}$ Edn., Butterworth- Heinemann Elsevier Ltd, Oxford, United Kingdom (2010).

Kaewsuk, J., W. Thorasampan, M. Thanuttamavong and G.T. Seo: Kinetic development and evaluation of membrane sequencing batch reactor (MSBR) with mixed cultures photosynthetic bacteria for dairy wastewater treatment. J. Environ. Manage., 91, 1161$1168(2010)$.

Karadag, D., O. E. Köroğlu, B. Ozkaya and M. Cakmakci: A review on anaerobic biofilm reactors for the treatment of dairy industry wastewater. Process Biochemistry, 50, 262-271 (2015).

Khan, S. J., S. Ilyas, S. Javid, C. Visvanathan and V. Jegatheesan: Performance of suspended and attached growth MBR systems in treating high strength synthetic wastewater. Bioresour.Technol, 102,5331-5336 (2011).

Langergraber, G., L. Reiger, S. Winkler, J. Alex, J. Wiese, C. Owerdieck, M. Ahnert, J. Simon and M. Maurer : A guide for simulation studies of wastewater treatment plants. Water Sci.Technol., 50, 131-138 (2004).

Li, Y. Z., Y. L. He, D. G. Ohandja, J. Ji, J. F. Li and T. Zhou: Simultaneous nitrification-denitrification achieved by an Innovative internal-Ioop airlift MBR : Comparative study. Bioresour. Technol., 99, 5867$5872(2008)$.

Liang, Z., A. Das, D. Beerman and Z. Hu : Biomass characteristics of two types of submerged membrane bioreactors for nitrogen removal from wastewater. Water Res., 44, 3313-3320 (2010).

Liu, Q. X. C. Wang, Y. Liu, H. Yuan and Y. Du: Performance of a hybrid membrane bioreactor in municipal wastewater treatment. Desalination, 258, 143-147 (2010).

Liwarska-Bizukojc, E. and R. Biernacki: Identification of the most sensitive parameters in the activated sludge model implemented in BioWin software. Bioresour. Technol., 101, 7278-7285(2010).

Mardani, Sh., A. Mirbagheri, M.M. Amin and M. Ghasemian: Determination of biokinetic coefficients for activated sludge processes on municipal wastewater Iran. J. Environ. Hlth. Sci. 
Eng., 8, 25-34 (2011).

Metcalf and Eddy: Wastewater Engineering: Treatment and Resource Recovery. $5^{\text {th }}$ Edn., McGraw-Hill Education, NewYork, p.600 (2014).

Nguyen, D. D., Huu Hao Ngo, Sa Dong Kirm and Yong Soo Yoon: A specific pilot-scale mernbrane hybrid treatment system for municipal wastewater treatment. Bioresour. Technol., 169, 52-61 (2014).

$\mathrm{Ni}$, B. J., and H. Q. Yu: An approach for modeling two-step denitrification in activated sludge systems. Chem. Eng. Sci, 63, 1449-1459 (2008).

Ohlan, R.: Competitiveness and trade performance of India's Dairy Industry. Asian J. Agri. Develop., 11, 18-37 (2014).

Rajesh Banu, J., S. Anandan, S. Kaliappan and I. T. Yeom: Treatment of dairy wastewater using anaerobic and solar photocatalytic methods. Solar Energy, 82, 812-819 (2008).

Shete, B.S. and N.P. Shinkar: Dairy industry wastewater sources, characteristics and its effects on environiment. $I$. J. Curr. Eng. Technol., 3, 1611-1615(2013).

Slavov, A.K.: General Characteristics and treatment possibilities of dairy wastewater-Areview. Food Technol. Biotechnol, 55, 14-28 (2017).

Subtil, E. L., J. C. Mierzwa and I. Hespanhol: Comparison between a conventional membrane bioreactor (C-MBR) and a biofilm membrane bioreactor (BF-MBR) for domestic wastewater treatment. Brazilian J. Chem. Eng., 31, 683-691 (2014).
Sun, C., T. O. Leiknesa, J. Weitzenböckb and B. Thorstensenc: Development of an integrated shipboard wastewater treatment system using biofllm-MBR. Separ. Purif. Technol, 75, 22-31 (2010).

Tiwari, S., C. R. Behera and B. Srinivasan: Simulation and experimental studies to enhance water reuse and reclamation in India's largest dairy industry. J. Environ. Chem. Eng., 4, 605-616 (2016).

Verkatesan, K., M. K. Saseetharan and V. Arutchelvan: Determination of bio-kinetic coefficients for dairy waste water. J. Indu. Pollu. Control, 20, 7-16 (2004).

Verma, M. R., B. Singh, S. Prasad and S. Kumar: Present status of trade of the dairy products in India. Int. J. Agric. Stat. Sci, 8, 469-474 (2012).

Vourch, M., B. Balannec, B. Chaufer and G. Dorange: Treatment of dairy industry wastewater by reverse osmosis for water reuse. Desalination, 219, 190-202 (2008).

Yang, S., F. Yang, Z. Fu and R. Lei: Comparison between a moving bed membrane bioreactor and a conventional membrane bioreactor on organic carbon and nitrogen removal. Bioresour. Technol, 100, 2369-2374 (2009).

Zhang, W., B. Tang and L. Bin: Research progress in biofilm-membrane bioreactor: A critical review. Indus. Eng. Chem. Res., 56, 69006909 (2017). 